\title{
How are legal matters related to the access of traditional knowledge being considered in the scope of ethnobotany publications in Brazil?
}

\author{
Heitor Suriano Nascimento Liporacci ${ }^{1,2^{*}}$, Tatiana Mota Miranda ${ }^{1,3}$, Natalia Hanazaki ${ }^{1,2}$ and Nivaldo Peroni ${ }^{1}$
}

Received: October 14, 2014 Accepted: January 05, 2015

\begin{abstract}
Legal measures, such as the use of free or prior and informed consent, return of research results to communities (which can be understood as "sharing of benefits," according to Brazilian legislation), and research authorization by governmental bodies, are mentioned and regulated in various documents, either governmental or specific, within the area of ethnobiology. This study aims to explore how these matters are considered in the scope of published ethnobotany articles in Brazil, as well as whether the creation of the Provisional Measure 2.186-16/2001 has contributed to the national advance of these matters. The methodology comprised a literature review of articles focusing on medicinal and food plant resources in the prominent Brazilian journals which publish ethnobotany studies. From 137 articles analyzed, 8 mentioned the return of research results to the community; 21 explicitly cited the use of free or prior and informed consent; and 13 mentioned the authorization of governmental bodies. We expect that the present study will contribute to the debate regarding the necessity of reformulation of the current system, which would guarantee a more effective rapport between the government, researchers, local communities, and society and contribute to the development of ethnobotany in Brazil.
\end{abstract}

Keywords: Brazil, Council of Genetic Heritage Management (CGEN), literature review, Provisional Measure, traditional knowledge

\section{Introduction}

The use of genetic resources and associated traditional knowledge has been conducted for a long time in an asymmetric manner. Historically, many natural resources have been appropriated by developed countries without proper access request from, prior consent of, or benefit-sharing with countries and communities, which originally provided and detained such resources (MMA 2013). This reality was justified by the ease of facilitated access to genetic resources before the Convention of Biological Diversity (CBD) (Cunha 1999; MMA 2005; Andrade et al. 2013; Ferreira \& Sampaio 2013). In addition, within the realm of science, during the pre-CBD phase, interactions between researchers and the use of biodiversity was not regulated by specific norms regarding access to resources and asso- ciated traditional knowledge as well as potential political, economic, and social implications resulting from some studies (Albuquerque et al. 2013). In contrast, intellectual property and patents have been regulated by international mechanisms, which are not often compatible with the free circulation of local knowledge (Cunha 1999).

During the 1980s, the first international regulatory body for the access of phytogenetic resources was created: The International Treaty on Plant Genetic Resources for Food and Agriculture (ITPGRFA) was adopted during the $22^{\text {nd }}$ Food and Agriculture (FAO) conference in 1983 and signed by 133 countries (Santilli 2009). According to Cunha (1999), strong resistance to the generalized privatization of resources (the principle of free access without restrictions) during the 1970s and beginning of 1980s was the reason for instituting such a regulatory body.

\footnotetext{
${ }^{1}$ Laboratório de Ecologia Humana e Etnobotânica, Departamento de Ecologia e Zoologia, Centro de Ciências Biológicas, Universidade Federal de Santa Catarina, 88040-900, Florianópolis, SC, Brazil

${ }^{2}$ Programa de Pós Graduação em Biologia de Fungos, Algas e Plantas, Centro de Ciências Biológicas, Universidade Federal de Santa Catarina, 88040-900, Florianópolis, SC, Brazil

${ }^{3}$ Programa de Pós-Graduação em Desenvolvimento Rural, Departamento de Economia e Relações Internacionais, Universidade Federal do Rio Grande do Sul, 90040-060, Farropilhas, Porto Alegre, RS, Brazil

"Corresponding author: hliporacci@hotmail.com
} 
The United Nations Conference on Environment and Development/Earth Summit in Rio de Janeiro, in 1992, approved the CBD text signed by 157 countries, including Brazil (Santilli 2009), and projected changes in the manner biodiversity would be used and explored (MMA 2005; Andrade et al. 2013). The CBD recognized the sovereignty of the signatory countries over their biological resources (MMA 2000; Ferreira \& Sampaio 2013), and established that the authority to govern access to genetic resources belongs to national governments under national legislation (MMA 2000; Santilli 2009). Moreover, it was decreed that researchers have a duty of sharing the benefits of their research, and acknowledged that local and indigenous communities have rights over their knowledge (MMA 2013) and therefore researches should always respect an established prior consent process (Santilli 2009; Bernardocki 2013).

Among CBD participant countries, Brazil was one of the first megadiverse countries that attempted to implement the convention objectives and to adopt an internal regimen for protecting and controlling the access of genetic resources and associated traditional knowledge, through the draft bill 306/1995 (Santilli 2013; Ferreira \& Sampaio 2013). Three years later, in 1998, two other bills, including Brazilian genetic assets under the Union's authority were presented (MMA 2005). In the early 2000s, after a series of accusations of biopiracy involving a Brazilian association and a pharmaceutical company (Ferreira \& Sampaio 2013), the federal government released the Provisional Measure (PM) 2.052 on June 29, 2000 (Andrade et al. 2013). This bill was modified and reedited as the PM 2.186-16 on August 23, 2001; it is still in force today, and establishes norms for regulating access to genetic resources and associated traditional knowledge in Brazil (MMA 2005).

The PM 2.186-16/2001 also created the Council of Genetic Heritage Management (CGEN). This council is responsible for deliberating processes related to access to genetic assets for bioprospecting and technological development, access to associated traditional knowledge for any objective, and accreditation of depositary institutions (MMA 2005). Ethnobiologists who already followed the Code of Ethics from the International Society of Ethnoecology, which was drafted in 1988 through the Declaration of Belém, now had to prove their ethical integrity and validate their work before conducting any research activities (Albuquerque et al. 2013). In addition to creating the PM 2.186-16/2001 and the CGEN, it is important to emphasize that during 2001, the International Treaty on Plant Genetic Resources for Food and Agriculture was expanded to focus on conservation and sustainable use of plant genetic resources, agriculture, and the fair and equitable sharing of benefits, thus guaranteeing the rights of farmers to agrobiodiversity (Santilli 2009).

The use and application of prior and informed consent, benefit-sharing with involved communities, and project authorization by governmental bodies are legal measures guided and shared not only by the CBD norms, PM 2.186-
16/2001, and CGEN but also by the Brazilian Society of Ethnobiology and Ethnoecology. In addition, prior informed consent is also required by the Health National Council's resolution 196/1996. Moreover, there is extensive literature published in Brazil and other countries highlighting the importance of abiding by these legal measures. In Brazil, for example, prior and informed consent is regarded as a fundamental aspect in the methodology of scientific activities (Albuquerque \& Hanazaki 2006; Albuquerque et al. 2010a); others emphasize the importance of returning results to communities and the sharing of benefits (Patzlaff \& Peixoto 2009; Albuquerque et al. 2010b).

In this article, we consider that access authorization is regarded as authorization granted through the process of submitting projects, which involves providing access to genetic resources and associated traditional knowledge to governmental bodies designated by the PM 2.186-16/2001 and later norms related to this PM, such as CGEN, Brazilian Institute for the Environment and Natural Resources (IBAMA), Indian National Foundation (FUNAI), National Council for Scientific and Technological Development (CNPq), National Historic and Artistic Heritage Institute (IPHAN), and Research Ethics Committees of the Universities, which could vary depending on the theme and objectives of the research (MMA 2005; Ferreira \& Sampaio 2013). It is important to emphasize that our focus is on the traditional knowledge associated with genetic resources and not on the authorizations required in the context of bioprospecting and technological development. In addition, according to the National Health Council's Resolution 196/1996, all research directly or indirectly involving humans is subject to the approval of Ethics Committees (Albuquerque et al. 2010a).

Free or prior and informed consent is understood here as a mandatory document to be attached to the research project and sent to the appropriate regulatory institutions as a prerequisite for obtaining the authorization for research activities (MMA 2005). This document must include information regarding the main steps of the research, such as the objective, methods, and techniques to be employed, as well as other information important to clarify and anticipate questions from the participants (Albuquerque et al.2010a). In addition, the document must address identity protection for participants in the processes of collecting data and publication (Albuquerque et al. 2010a).

With regard to returning information to the people or sharing the results with the groups or communities studied, it is important to highlight that this measure can be a dynamic process that can also be seen as more applied activities, achieved by returning information in a systematic manner, in the forms of field guides and talks, among others (Patzlaff \& Peixoto 2009; Albuquerque et al. 2010b) or actions developed to contribute to local development, considering their problems, demands, and collective interests (Albuquerque et al. 2010b). Moreover, returning and sharing information can involve participatory research and 
educational approaches that may require a wide approach toward acknowledging traditional knowledge and culture.

Although there have been historical and political milestones and increased research on this theme (Bridges 2004; MMA 2005; Albuquerque \& Hanazaki 2006; Patzlaff \& Peixoto 2009; Albuquerque et al. 2010b), some authors have expressed concerns regarding ethical conduct and practices by certain researchers in ethnobiology, an interdisciplinary field that originated between biological and human sciences.

In the context of how research has been conducted and the issue of compliance with legal norms, this study aims to analyze how the results of ethnobotany research are shared with communities and how prior and informed consent and authorization of governmental bodies have been considered in articles published in the prominent Brazilian ethnobotany journals, through a bibliographic review. In addition, we aim to discuss how the creation of the PM 2.186-16/2001 has contributed to advance and improve the maturity of the considerations regarding these issues in Brazil. Our objective is to foster reflection and debate regarding the interaction among research, government, and societal spheres in relation to legal aspects and involving access to genetic resources and associated traditional knowledge.

\section{Material and methods}

We conducted a literature review for ethnobotany articles published in Brazilian journals: Acta Amazônica, Acta Botanica Brasilica, Anais da Academia Brasileira de Ciências, Boletim do Museu Paraense Emílio Goeldi (Boletim de Ciências Naturais/ Ciências Humanas), Ethnobiology and Conservation, Biotemas, Revista Brasileira de Biociências, Revista Brasileira de Farmacognosia, Revista Brasileira de Plantas Medicinais, and Rodriguésia. These journals were selected based on analysis of the prominent ethnobotany studies published in journals in Brazil (Liporacci 2014). Articles were accessed according to their availability on journal websites, from their first volumes to the latest publication until 2012. Selected articles necessarily included local knowledge and food and/or medicinal species use. It is important to highlight that studies under an ethnobotanical/ ethnopharmacological interface as well as those performed on open markets were also considered in this review.

Due to various ways by which authors treated research themes, it was necessary to develop a set of criteria for their classification. Returning or sharing data and results with communities was classified under three categories: $a c$ complished, suggested, and not mentioned. An accomplished return of information to communities was when authors described what was performed and how it contributed to local communities; a suggested return was when authors suggested some type of measure; and return not mentioned when authors did not mention in any way the accomplishment, pretension, or suggestion of a return of data and results to the communities. Prior and informed consent was also divided into three categories: explicit consent, implicit consent, and consent not mentioned. The first refers to whenever articles made a clear statement of how prior and informed consent was guaranteed; the second refers to articles that did not make a clear statement about the use of prior and informed consent; and the last did not mention prior and informed consent at all. As for authorization by governmental bodies, we analyzed whether this process was mentioned, regardless of studied groups and possible exceptions within present legislation.

Additionally, we analyzed norms used by selected journals to investigate whether they mentioned publishing requirements related to the studied ethical and legal matters. Finally, a temporal analysis was performed to verify whether the creation of the PM 2.186-16/2001 has contributed to an increase in legal and ethical considerations by authors within the selected articles.

\section{Results}

A total of 137 articles were compiled from 1977 to 2012. The majority of the articles were from Acta Botanica Brasilica and Revista Brasileira de Plantas Medicinais (Tab. 1).

From all the analyzed articles, $53.28 \%$ did not mention any pretention to return data to communities, whereas $40.88 \%$ suggested some type of activity and only $5.84 \%$ mentioned accomplished actions of returning data to communities (Tab. 2).

Prior and informed consent was not mentioned in $72.99 \%$ of the articles. In $11.68 \%$ of articles, it is not clear whether this was employed, and in only $15.33 \%$ did authors mention the use of prior and informed consent (Tab. 2).

Only 13 articles mentioned research authorization by regulating governmental bodies. Of these, six had authorization from the Ethics Committee of the involved institution, three mentioned only an authorization by the CGEN, two mentioned authorization by the CGEN and Ethics Committee, and one article mentioned authorization by a different regulating body such as IBAMA through the Biodiversity System of Authorization and Information. Moreover, some authors presented numerous authorization processes, highlighting the diversity of ways in which legal aspects can be mentioned in articles.

With regard to the analysis of legal and ethical norms by the scientific journals studied, we did not find any requirements concerning the return of results to the communities. As for prior and informed consent, only the Ethnobiology and Conservation journal mentioned that authors must indicate consent from local informants. In terms of authorization by governmental bodies, there were requirements in four journals: Revista Brasileira de Farmacognosia, Acta Amazônica, Anais da Academia Brasileira de Ciências, and Ethnobiology and Conservation. Within Acta Amazônica guidelines, there is a specific item concerning legal and ethical aspects, which clarifies the organs that are suitable 
Table 1. Articles selected for the literature review, classified according to decade.

\begin{tabular}{ccc}
\hline 1970-1979 (1 ARTICLE) & 1980-1989 (2 ARTICLES) & 1990-1999 (1 ARTICLE) \\
\hline Anderson 1977 & Miller et al. 1989; Grandi et al. 1989 & Rodrigues 1998 \\
\hline
\end{tabular}

Castellucci et al. 2000; Costa-Neto \& Oliveira 2000; Dorigoni et al. 2001; Garlet \& Irgang 2001; Marodin \& Baptista 2001; Parente \& Rosa 2001; Albuquerque \& Andrade 2002; Amorozo 2002; Ghedini et al. 2002; Marodin \& Baptista, 2002; Pinheiro 2002; Ritter et al. 2002; Silva \& Andrade 2002; Barbosa \& Pinto 2003; Nunes et al. 2003; Verde et al. 2003; Fonseca-Kruel \& Peixoto 2004; Macedo \& Ferreira 2004; Medeiros et al. 2004a; Medeiros et al. 2004b; Rocha et al. 2004; Soares et al. 2004; Albuquerque et al. 2005; Alvino et al. 2005; Bueno et al. 2005; Macedo \& Ferreira 2005; Martins et al. 2005; Martins \& Oliveira 2005; Morais et al. 2005; Pasa et al. 2005; Pereira et al. 2005a; Pereira et al. 2005b; Rocha \& Silva 2005; Silva \& Albuquerque 2005; Silva \& Andrade 2005; Andrade et al. 2006; Azevedo \& Silva 2006; Borba \& Macedo 2006; Botrel et al. 2006; Christo et al. 2006; Falcão et al. 2006; Ferraz et al. 2006; Franco \& Barros 2006; Freitas \& Fernandes 2006; Hanazaki et al. 2006; Pilla et al. 2006; Pinto et al. 2006; Rodrigues \& Guedes 2006; Roman \& Santos 2006; Silva et al. 2006a; Silva et al. 2006b; Souza \& Felfili 2006; Vendruscolo \& Mentz 2006; Zeni \& Bósio 2006; Florentino et al. 2007; Maioli-Azevedo \& Fonseca-Kruel 2007; Marinho et al. 2007; Negrelle \& Fornazzali, 2007; Negrelle et al. 2007; Ribeiro et al. 2007; Rodrigues \& Carvalho 2007; Souza 2007; Vieira et al. 2007; Yuyama et al. 2007; Calábria et al. 2008; Cunha-Lima et al. 2008; Melo et al. 2008; Miranda \& Hanazaki, 2008; Rufino et al. 2008; Santos et al. 2008; Silva \& Proença 2008; Baldauf et al. 2009; Borges \& Peixoto 2009; Castro et al. 2009; Eichemberg et al. 2009; Fonseca-Kruel et al. 2009; Jesus et al. 2009; Lanini et al. 2009; Leitão et al. 2009; Marchese et al. 2009; Oliveira \& Trovão 2009; Pilla \& Amorozo 2009; Pires et al. 2009; Santos et al. 2009; Scoles 2009; Ustulin et al. 2009.

\section{0-2012 (47 ARTICLES)}

Albertasse et al. 2010; Almeida \& Bandeira 2010; Althaus-Ottman et al. 2010; Barroso \& Hanazaki 2010; Carneiro et al. 2010; Carniello et al. 2010; Christo et al. 2010; Costa \& Mitja 2010; Giraldi \& Hanazaki 2010; Merétika et al. 2010; Oliveira et al. 2010a; Oliveira et al. 2010b; Oliveira et al. 2010c; Roque et al. 2010; Silva et al. 2010; Silva \& Freire 2010; Zuchiwschi et al. 2010; Brito \& Senna-Valle 2011; Costa \& Mayworm 2011; Cunha \& Bortoloto 2011; Gandolfo \& Hanazaki 2011; Lima et al. 2011; Marinho et al. 2011; Oliveira et al. 2011; Mattos et al. 2012; Miranda \& Hanazaki et al. 2011; Siviero et al. 2011; Silva et al. 2011; Aguiar \& Barros 2012; Araújo \& Amorozo 2012; Brito \& Senna-Valle 2012; Castro et al. 2012; Chaves \& Barros 2012; Cunha-Lima et al. 2012; Espinosa et al. 2012; Freitas et al. 2012; Gomes \& Bandeira 2012; González-Perez et al. 2012; Lima et al. 2012; Lucena et al. 2012; Nunes et al. 2012; Oliveira \& Menini-Neto 2012; Paulino et al. 2012; Poderoso et al. 2012; Rosa et al. 2012; Santos \& Coelho-Ferreira 2012; Siviero et al. 2012.

Table 2. Number of articles per journal for the categories of returning/sharing results and prior and informed consent.

\begin{tabular}{|c|c|c|c|c|c|c|c|}
\hline \multirow{2}{*}{ JOURNALS } & \multicolumn{3}{|c|}{$\begin{array}{l}\text { RETURN OF RESEARCH RESULTS } \\
\text { TO THE COMMUNITIES }\end{array}$} & \multicolumn{3}{|c|}{ PRIOR AND INFORMED CONSENT } & \multirow{2}{*}{$\begin{array}{c}\text { Total Selected } \\
\text { Articles by } \\
\text { journal }\end{array}$} \\
\hline & Accomplished & Suggested & $\begin{array}{c}\text { Not } \\
\text { mentioned }\end{array}$ & Implicit & Explicit & $\begin{array}{c}\text { Not } \\
\text { mentioned }\end{array}$ & \\
\hline $\begin{array}{l}\text { Revista Brasileira de Plantas } \\
\text { Medicinais }\end{array}$ & $\begin{array}{c}2 \\
(5 \%)\end{array}$ & $\begin{array}{c}19 \\
(47.5 \%)\end{array}$ & $\begin{array}{c}19 \\
(47.5 \%)\end{array}$ & $\begin{array}{c}3 \\
(7.5 \%)\end{array}$ & $\begin{array}{c}4 \\
(10 \%)\end{array}$ & $\begin{array}{c}33 \\
(82.5 \%)\end{array}$ & 40 \\
\hline $\begin{array}{l}\text { Revista Brasileira de } \\
\text { Farmacognosia }\end{array}$ & 0 & $\begin{array}{c}3 \\
(14.29 \%)\end{array}$ & $\begin{array}{c}18 \\
(85.71 \%)\end{array}$ & $\begin{array}{c}2 \\
(9.52 \%)\end{array}$ & $\begin{array}{c}4 \\
(19.05 \%)\end{array}$ & $\begin{array}{c}15 \\
(71.43 \%)\end{array}$ & 21 \\
\hline Acta Botanica Brasilica & $\begin{array}{c}4 \\
(8.51 \%)\end{array}$ & $\begin{array}{c}22 \\
(46.81 \%)\end{array}$ & $\begin{array}{c}21 \\
(44.68 \%)\end{array}$ & $\begin{array}{c}10 \\
(21.28 \%)\end{array}$ & $\begin{array}{c}9 \\
(19.15 \%)\end{array}$ & $\begin{array}{c}28 \\
(59.57 \%)\end{array}$ & 47 \\
\hline Rodriguesia & $\begin{array}{c}1 \\
(16.67 \%)\end{array}$ & $\begin{array}{c}2 \\
(33.33 \%)\end{array}$ & $\begin{array}{c}3 \\
(50 \%)\end{array}$ & $\begin{array}{c}1 \\
(16.67 \%)\end{array}$ & $\begin{array}{c}1 \\
(16.67 \%)\end{array}$ & $\begin{array}{c}4 \\
(66.66 \%)\end{array}$ & 6 \\
\hline Acta Amazônica & 0 & $\begin{array}{c}3 \\
(27.27 \%)\end{array}$ & $\begin{array}{c}8 \\
(72.72 \%)\end{array}$ & 0 & 0 & $\begin{array}{c}11 \\
(100 \%)\end{array}$ & 11 \\
\hline $\begin{array}{l}\text { Revista Brasileira de } \\
\text { Biociências }\end{array}$ & 0 & $\begin{array}{c}2 \\
(40 \%)\end{array}$ & $\begin{array}{c}3 \\
(60 \%)\end{array}$ & 0 & $\begin{array}{c}1 \\
(20 \%)\end{array}$ & $\begin{array}{c}4 \\
(80 \%)\end{array}$ & 5 \\
\hline $\begin{array}{l}\text { Anais da Academia Brasileira } \\
\text { de Ciências }\end{array}$ & $\begin{array}{c}1 \\
(100 \%)\end{array}$ & 0 & 0 & 0 & 0 & $\begin{array}{c}1 \\
(100 \%)\end{array}$ & 1 \\
\hline Biotemas & 0 & $\begin{array}{c}2 \\
(66.67 \%)\end{array}$ & $\begin{array}{c}1 \\
(33.33 \%)\end{array}$ & 0 & $\begin{array}{c}1 \\
(33.33 \%)\end{array}$ & $\begin{array}{c}2 \\
(66.67 \%)\end{array}$ & 3 \\
\hline Revista Museu Goeldi & 0 & $\begin{array}{c}2 \\
(100 \%)\end{array}$ & 0 & 0 & 0 & $\begin{array}{c}2 \\
(100 \%)\end{array}$ & 2 \\
\hline $\begin{array}{l}\text { Ethnobiology and } \\
\text { Conservation }\end{array}$ & 0 & $\begin{array}{c}1 \\
(100 \%)\end{array}$ & 0 & 0 & $\begin{array}{c}1 \\
(100 \%)\end{array}$ & 0 & 1 \\
\hline TOTAL & $8(5.84 \%)$ & $56(40.88 \%)$ & $73(53.28 \%)$ & $16(11.68 \%)$ & $21(15.33 \%)$ & $100(72.99 \%)$ & 137 \\
\hline
\end{tabular}

for research authorization, and there is a requirement for a protocol number and approval date. Revista Brasileira de Farmacognosia requires only authorization by the Ethics Committee from the institution from which the research originates. Anais da Academia Brasileira de Ciências and Ethnobiology and Conservation require authors to mention the Ethics Committee approval within the Material and Methods section. Among the aforementioned four jour- nals, only Ethnobiology and Conservation clearly mentions that a lack of legal procedures may result in a rejection of manuscripts by reviewers.

Temporal and historical analyses highlight the presence of two distinct periods (Fig. 1): the first, between 1977 and 2000 (referring to the date of the oldest selected article to the year of the enactment of PM 2.186-16/2001), and the second, between 2001 and 2012 (referring to the year of the 


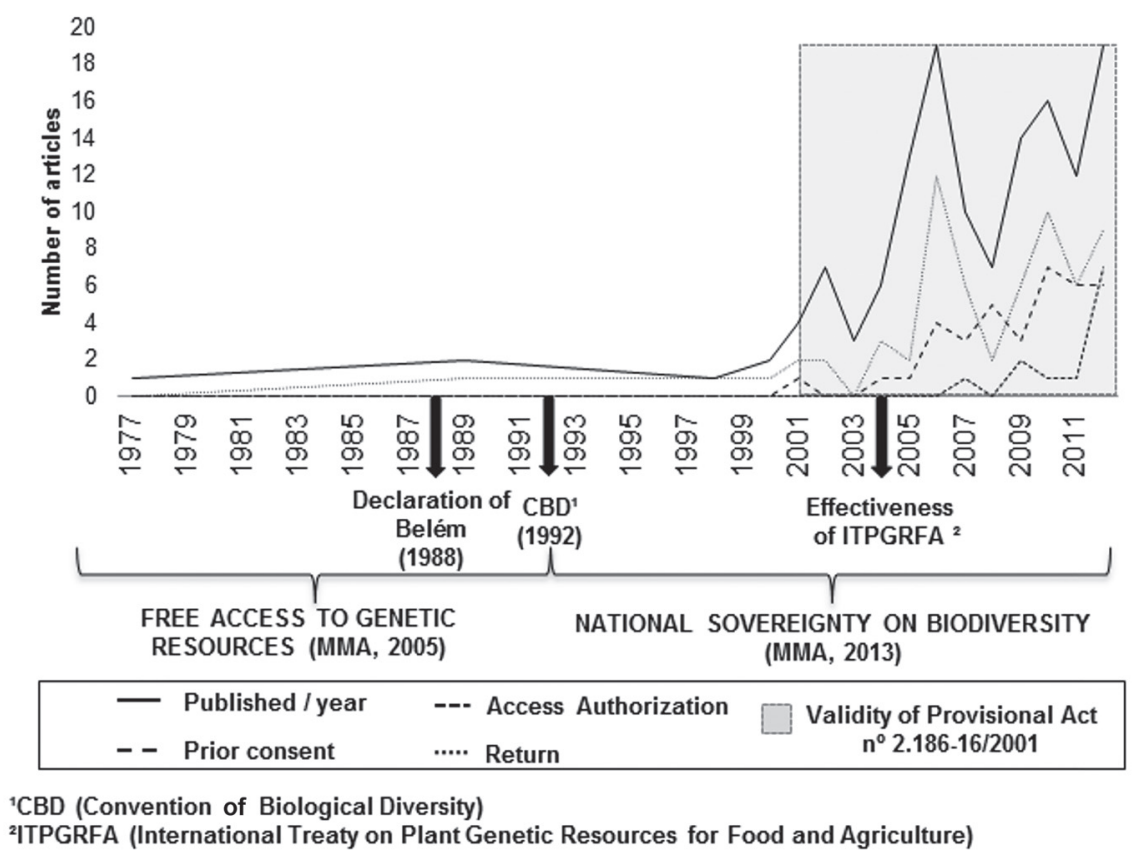

Figure 1. Temporal analysis of the considerations of legal issues in ethnobotanical articles regarding knowledge and use of medicinal and food plants between 1977 and 2012.

enactment of PM 2.186-16/2001 to the last year used for selecting articles for this study). It is important to note that within the first period (1977-2000), there are few mentions of legal matters and a few publications (six articles). In the next period (2001-2012), there is an increase in mentions of legal aspects and in the number of publications (131 articles).

\section{Discussion}

A considerable number of researchers are apparently not complying with legal obligations regarding the access to genetic heritage and associated traditional knowledge (Tab. 1). However, we emphasize that we are dealing with the limitations of analyzing only the written structure of articles: many authors may have accomplished and complied with legal requirements, but they have not mentioned them in the article for several reasons. Therefore, it is important that this theme is not oversimplified or treated as a judgment but is considered in the diversity of situations in which ethnobotanical research is performed.

We have observed that even when we add the number of articles that explicitly mention actions of returning results to the number of articles that only suggest the actions, the amount does not reach half of the total selected articles (46.72\%). Thus, some authors discuss and comment on legal matters within ethnobotanical publications (Bridges 2004; Albuquerque \& Hanazaki 2006; Albuquerque et al. 2010a; Pérez-Ojeda del Arco et al. 2011). Bridges (2004) mention that authors need to dedicate a part of their articles to legal obligations, thereby sharing ideas about how to collaborate with local communities. The author also suggests a change on the side of reviewers and editors that would promote the acknowledgement of such measures. Albuquerque et al. (2010b) also state that this type of information would provide ideas about well-developed experiences in different geographical and cultural contexts. Albuquerque \& Hanazaki (2006) have noted the essential role of considering the ethical implications of research in the scope of discussions on access to associated traditional knowledge.

One can expect several impediments to developing and accomplishing the return or sharing of research results with communities. From an investigation of studies from different parts of the world, Pérez-Ojeda del Arco et al. (2011) elucidated the main difficulties in the process of returning results, such as limited funds and reduced time for research as determinant factors. Nevertheless, according to the same authors, these difficulties are distributed in a distinct manner, depending on countries, based on access to funding as well as the experience of researchers, because accomplished researchers receive greater recognition and funding (PérezOjeda del Arco et al. 2011). According to Albuquerque et al. (2010b), a concern with research interlocutors is sometimes a novel aspect for some researchers because they may lack an academic background that would guarantee the focus on ethical obligations within the studied subjects. They recommend a consolidation of wider academic education in ethnobotany that would consider ethical and philosophical principles related to benefit-sharing and allow questioning that would help researchers to critically think regarding the compliance with legal tools related to these matters (Albuquerque et al. 2013). 
It is necessary to consider that there are diverse ways of returning and sharing academic research results (Albuquerque et al. 2010b), which will vary according to the area of knowledge and type of research and according to local characteristics of and established agreements with studied communities (Patzlaff \& Peixoto 2009). Moreover, Patzlaff \& Peixoto (2009) state that the process of returning results is dynamic and that the researcher will have to adapt and adjust to it according to the observations and necessities of the community.

It is assumed that assimilation time, understanding, and choice of the most appropriate type of research results to return does not correspond to the time of a graduate program, such as a masters degree. The idea of including considerations regarding these issues in articles for publication is an interesting measure to stimulate and widen the visibility of such matters and to foster future developments in returning results and benefit sharing to the communities.

Results concerning the use of prior and informed consent may also seem to be alarming because $72.99 \%$ of articles lack any mention of its employment. However, as stated before, it is not possible to analyze the ethical conduct of researchers only through these data. On the other hand, there are factors that contribute to the situation mentioned above. Bureaucracy and tardiness in the processing and analysis of projects within institutional bodies may encourage some researchers to opt for obtaining prior verbal consent, which can have the same objectives of written consent, but does not require signatures and a printed official document. Depending on the context of the local communities, requiring a signature for an official document can generate discomfort, refusals, or even legal implications for the communities, such as in the case of people living within Protected Areas of full-protection status (Peroni et al. 2007).

It is possible to associate the use of prior and informed consent with authorizations by governmental bodies because consent documents are prerequisites for the authorization of research work (MMA 2005). However, we noted that two authors have cited a CGEN authorization and also the use of prior and informed consent. This may reveal different understandings among researchers in the manner to present such information in the articles. There is certainly asymmetry regarding these procedures between the researchers towards research subjects and efforts towards bureaucratic processes.

Apart from bureaucratic and political problems regarding the implementation of prior and informed consent, it is possible that some researchers are simply unaware of such matters. This lack of awareness may be due to the accelerated growth in field since the 2000s, revealing a new generation of researchers in ethnobiology including those uninformed regarding legal procedures involving their research. However, according to McClatchey (2006), Brazilians have easy access to a wide array of literature, including those of international distribution, which would not justify the lack of basic procedures and standardized methodologies in their research.

The reduced number of articles mentioning submissions and authorizations of research by governmental bodies such as CGEN is possibly connected to the required bureaucracy in the processing and analysis of projects. Platiau \& Varella (2004) assert that Brazil has created an inefficient and bureaucratic structure for managing requests of access through the PM 2.186-16/2001, and Albuquerque et al. (2010a) argue that the various problems should be solved, so that research in this field is not jeopardized. Such incompatibility between regulatory bodies and research reality in Brazil has also been discussed by Peroni et al. (2007), who emphasize that graduate students have been encountering many impediments for reconciling their time for developing research and academic obligations to the legal requirements of such bodies.

In the face of issues involving these measures, it is important to note that since 2003, proposals for change of this legal framework have been under discussion (Ferreira \& Sampaio 2013). The public consultation carried out during 2008 at the time of debates regarding substituting the PM $2.186-16 / 2001$ by a draft bill, which would withdraw the need for authorizations and approvals for research, serves as an example (Albuquerque et al. 2010a). As a response to numerous manifestations and criticism to PM 2.18616/2001 and CGEN, some governmental initiatives have been recently underway to facilitate a more agile process, with accreditation by IBAMA, CNPq, and IPHAN for expedited authorizations (Andrade et al. 2013). Notably, the degree of dissatisfaction and anxiety in relation to barriers posed by the government since the PM has been enacted. More than 10 years have passed and until now, the PM $2.186-16 / 2001$ was not yet completely assessed by politicians, representing a setback to contributions for knowledge, conservation, and sustainable development for national megabiodiversity (Andrade et al. 2013). However, increasing the discussion regarding this theme can certainly contribute with the development of more adequate legal frameworks for the Brazilian reality.

There is some flexibility in relation to the requirements for describing legal matters within journals because these descriptions are not consistently a main prerequisite for acceptance and publication of manuscripts. Therefore, the lack of precision in specific guidelines related to legal and ethical matters may represent a contributing factor in authors failing to mention these aspects in the articles submitted, even though they might have had proper authorizations from competent bodies. In addition, scientific journals have opted for objectivity in published articles that could potentially discourage descriptions of legal and ethical procedures. However, editorials of some international journals such as the Journal of Ethnopharmacology (Verpoorte et al. 2006) and Economic Botany (Moerman 2005) reflect the trend of increasing rigor for accepting ethnobotanical and ethnopharmacological research in light of these matters, 
pointing to specific criteria that require inclusion of specific methodological information, such as legal issues involving local communities (Albuquerque et al. 2010a).

As for the temporal analysis of selected scientific production, we noticed that until 2000, the number of publications, both the general ethnobotanical research and mentioning legal or ethical matters, were relatively small. These findings reflect the fact that some of these publications are pre-CBD and that, until then, there was no incisive direction on increasing the control of access to genetic resources and associated traditional knowledge. From the analyzed period of 2001-2012, we observed an increase both in number of publications (Oliveira et al. 2009) and in the number of mentions of legal measures, which could be explained by the PM 2.186-16/2001, the creation of CGEN, and the influence of the ITPGRFA, which improved visibility and posed a more rigorous enforcement in relation to compliance with legal matters and acknowledgement of local communities and rights of farmer. Moreover, the current concern with conservation of biodiversity and social/ cultural diversity, ethics, protection, and acknowledgement of the rights of local communities, has been regarded with great importance worldwide. According to Hunn (2007), this period also characterizes a recent phase in the field of ethnobiology, which emphasizes the rights of indigenous peoples for the control of their own traditional knowledge and also contributes to the commoditization of such knowledge when the access and control of knowledge begin to be linked to commercial regulatory measures, such as patent laws (Cunha 1999; Alexiades 2003). In addition, during this period, different Brazilian and international authors emphasize the importance of discussing and revealing legal measures within publications in the area (Shanley \& Laird 2002; Bridges 2004; Albuquerque \& Hanazaki 2006; Patzlaff \& Peixoto 2009; Albuquerque et al. 2010a; Pérez-Ojeda del Arco et al. 2011).

\section{Conclusions}

It is important to highlight that the intention of the present study was to contribute to critical reflections in relation to legal obligations outlined between the researcher and subjects. In addition, this study contributes in the context of access to traditional knowledge associated with biodiversity. In this context, it is essential to consider the distinct approaches among researchers in legal matters in the scope of published articles, indicating the influences of legal milestones and providing an opportunity for discussions about how the governmental, science, and societal spheres are integrated. This analysis clearly shows that such interactions need improvement from all actors involved.

Current legislation defines governmental bodies as responsible for evaluative activities related to accessing associated traditional knowledge; however, this is still far from the research reality in Brazil. Bureaucracy that involves obtaining authorization acts as a limiting factor for research instead of contributing to the advance of such studies. In addition, because of a lack of research planning for obtaining authorizations as well as lack of experience of these matters of a few researchers, scientific actors are becoming distant from the processes of building more comprehensive and socially sound policies. Furthermore, norms from the prominent Brazilian journals, which are open for ethnobotanical research, do not include specific guidelines around legal matters in research, particularly for research in ethnobiology, in majority of the cases. The positive side is that this lack of guidelines allows certain flexibility for authors in the fields of ethnobiology and ethnobotany. However, the importance of legal matters as fundamental elements in researching methodological procedures cannot be reinforced.

Temporal analysis and mentions of legal matters suggests that the creation of the PM 2.186-16/2001 has had significant impact in raising awareness regarding compliance with legal obligations, resulting in an increased number of mentions within articles. However, the criticism of societies toward the PM text over time (Andrade et al.2013) and the period of research inertia between the first enactment of the PM in 2000 and beginning of CGEN activities in April 2002 (Azevedo 2005) as well as all the challenges discussed above have led to major delays in the implementation of scientific and technological developments and advances expected in natural resources in Brazil (Andrade et al. 2013). Based on these facts, there is a notable and immediate need for a reformulation of the entire system to attend specifically and in time to demands from all parts and most importantly to prioritize respect and compliance with legal and ethical measures by both science and society.

We should recognize that although there is an evident need for establishing regulations related to access to associated traditional knowledge and biodiversity and for creating norms with certain flexibility, the processes will not always function in a homogenous manner for heterogeneous cases (Peroni et al. 2007). Solutions must be considered in a manner that legislation could fit the diverse nuances that comprise science because we live in one of the most bioculturally diverse countries in the world, which offers endless possibilities for research. It is necessary that science should mutually attend to every local community, society, and academic community (Albuquerque et al. 2010a). For this, it is essential that spheres of government, science, and society work together. Above all, it is fundamental to highlight the importance of understanding legal matters from an ethical and moral perspective as a researcher and not only as legal obligations because there is a demand for professionals engaged with scientific ethics and concerned with safeguarding knowledge and rights for local communities in Brazil. Finally, in the 10 years since the PM enactment and almost two decades since the CBD, one question remains: "do these measures actually function to protect the rights of communities over their traditional knowledge?" 


\section{Acknowledgements}

We thank Rubana Palhares Alves and Sofia Zank, who contributed to the discussion of previous versions of this manuscript. We are also grateful to $\mathrm{CNPq}$ for research productivity scholarships (N. Hanazaki, 306895/2009-9; N. Peroni, 307137/2012-0) and a postdoctoral scholarship (T.M. Miranda, PDJ 151321/2013-2).

\section{References}

Aguiar LCGG, Barros RFM. 2012. Plantas medicinais cultivadas em quintais de comunidades rurais no domínio do cerrado piauiense (Município de Demerval Lobão, Piauí, Brasil). Revista Brasileira de Plantas Medicinais, Botucatu 14: 419-434.

Albertasse PD, Thomaz LD, Andrade MA. 2010. Plantas medicinais e seus usos na comunidade da Barra do Jucu, Vila Velha, ES. Revista Brasileira de Plantas Medicinais, Botucatu 12: 250-260.

Albuquerque UP, Andrade LHC. 2002. Conhecimento botânico tradicional e conservação em uma área de caatinga no estado de Pernambuco, Nordeste do Brasil. Acta Botanica Brasilica 16: 273-85.

Albuquerque UP, Andrade LHC, Silva ACO. 2005. Use of plant resources in a seasonal dry forest (Northeastern Brazil). Acta Botanica Brasilica 19: 27-38.

Albuquerque UP, Araújo TAS, Soldati GT. 2010b. O "retorno" das pesquisas etnobiológicas para as comunidades. In: Albuquerque UP, Lucena RFP, Cunha LVFCC. (eds.) Métodos e técnicas na pesquisa etnobiológica e etnoecológica. Recife, NUPEEA. p. 481-488.

Albuquerque UP, Hanazaki N. 2006. As pesquisas etnodirigidas na descoberta de novos fármacos de interesse médico e farmacêutico: fragilidades e pespectivas. Revista Brasileira de Farmacognosia 16: 678-689.

Albuquerque UP; Hanazaki N, Melo JG. 2010a. Problemas e perspectivas na publicação de trabalhos em etnobiologia. In: Albuquerque UP, Lucena RFP, Cunha LVFCC. (eds.) Métodos e técnicas na pesquisa etnobiológica e etnoecológica. Recife, NUPEEA. p. 437-462.

Albuquerque UP, Hanazaki N, Santilli J. 2013. Acess and benefit-sharing in Brazil: towards the appropriation of the commons. In: Boef WS, Subedi A, Peroni N, Thijssen M, O'Keeffe MTE. (eds.) Community Biodiversity Management: Promoting resilience and the conservation of plant genetic resources. New York, Routledge. p. 328-333.

Alexiades MN. 2003. Ethnobotany in the Third Millennium: expectations and unresolved issues. Depinoa 45: 15-28.

Almeida VS, Bandeira FPS. 2010. O significado cultural do uso de plantas da caatinga pelos quilombolas do Raso da Catarina, município de Jeremoabo, Bahia, Brasil. Rodriguésia 61: 195-209.

Althaus-Ottmann MM, Cruz MJR, Fonte NN. 2011. Diversidade e uso das plantas cultivadas nos quintais do Bairro Fanny, Curitiba, PR, Brasil. Revista Brasileira de Biociências, Porto Alegre 9: 39-49.

Alvino FO, Silva MFF, Rayol BP. 2005. Potencial de uso das espécies arbóreas de uma floresta secundária, na Zona Bragantina, Pará, Brasil. Acta Amazônica 35: 413-420.

Amorozo MCM. 2002. Uso e diversidade de plantas medicinais em Santo Antônio do Leverger, MT, Brasil. Acta Botanica Brasilica 16: 189-203.

Anderson AB. 1977. Os nomes e usos de palmeiras entre uma tribo de índios Yanomama. Acta Amazônica 7: 5-13.

Andrade CTS, Marques JGW, Zappi DC. 2006. Utilização medicinal de cactáceas por sertanejos baianos. Revista Brasileira de Plantas Medicinais, Botucatu 8: 36-42.

Andrade RMG, Mossri BB, Nader HB. 2013. Pesquisa científica e acesso a recursos genéticos. In: Ferreira SN, Sampaio MJAM. (eds.) Biodiversidade e conhecimentos tradicionais associados: Implementação da legislação de acesso e repartição de benefícios no Brasil. São Paulo, Sociedade Brasileira para o Progresso da Ciência. p. 45-52.

Araujo CR, Amorozo MCM. 2012. Manutenção da diversidade agrícola em assentamentos rurais: um estudo de caso em Moji-Mirim - SP, Brasil. Biotemas 25: 265-280.
Azevedo CMAA. 2005. Regulamentação do acesso aos recursos genéticos e aos conhecimentos tradicionais associados no Brasil. Biota Neotropica: 5: 1-9.

Azevedo SKS, Silva IM. 2006. Plantas medicinais e de uso religioso comercializadas em mercados e feiras livres no Rio de Janeiro, RJ, Brasil. Acta Botanica Brasilica 20: 185-194.

Baldauf C, Kubo RR, Silva F, Irgang BE. 2009. "Ferveu, queimou o ser da erva”: conhecimento de especialistas locais sobre plantas medicinais na região Sul do Brasil. Revista Brasileira de Plantas Medicinais, Botucatu 11: 282-291.

Barbosa WLR, Pinto LN. 2003. Documentação e valorização da fitoterapia tradicional Kayapó nas aldeias A’Ukre e Pykanu-sudeste do Pará. Revista Brasileira de Farmacognosia 13: 47-49.

Barroso RM, Hanazaki N. 2010. Etnoecologia e etnobotânica da palmeira juçara (Euterpe edulis Martius) em comunidades quilombolas do Vale do Ribeira, São Paulo. Acta Botanica Brasilica 24: 518-528.

Bernardocki A. 2013. O artigo 26 da medida provisória n. 2.186-16, de 2001, e a responsabilidade civil por danos ao meio ambiente. In: Ferreira SN, Sampaio MJAM. Biodiversidade e conhecimentos tradicionais associados: Implementação da legislação de acesso e repartição de benefícios no Brasil. São Paulo, Sociedade Brasileira para o Progresso da Ciência. p. 57-66.

Borba AM, Macedo M. 2006. Plantas medicinais usadas para a saúde bucal pela comunidade do bairro Santa Cruz, Chapada dos Guimarães, MT, Brasil. Acta Botanica Brasilica 20: 771-782.

Borges R, Peixoto AL. 2009. Conhecimento e uso de plantas em uma comunidade caiçara do litoral sul do Estado do Rio de Janeiro, Brasil. Acta Botanica Brasilica 23: 769-779.

Botrel RT, Rodrigues LA, Gomes LJ, Carvalho DA, Fontes MAL. 2006. Uso da vegetação nativa pela população local no município de Ingaí, MG, Brasil. Acta Botanica Brasilica 20: 143-156.

Bridges KW. 2004. Editorial: Give and Take. Ethnobotany Research \& Applications 2 (75)

Brito MR, Senna-Valle LS. 2011. Plantas medicinais utilizados na comunidade caiçara da Praia do Sono, Paraty, Rio de Janeiro, Brasil. Acta Botanica Brasilica 25: 363-372.

Brito MR, Senna-Valle LS. 2012. Diversity of plant knowledge in a "Caiçara" community from the Brazilian Atlantic Forest coast. Acta Botanica Brasilica 26: 735-747.

Bueno NR, Castilho RO, Costa RB, et al. Medicinal plants used by the Kaiowá and Guarani indigenous populations in the Caarapó Reserve, Mato Grosso do Sul, Brazil. Acta Botanica Brasilica 19: 39-44.

Calábria L, Cuba GT, Hwang SM, et al. 2008. Levantamento etnobotânico e etnofarmacológico de plantas medicinais em Indianópolis, Minas Gerais, Brasil. Revista Brasileira de Plantas Medicinais, Botucatu 10: 49-63.

Carneiro DG, Barboza MS, Menezes MP. 2010. Plantas nativas úteis na Vila dos Pescadores da Reserva Extrativista Marinha Caeté-Taperaçu, Pará, Brasil. Acta Botanica Brasilica 24: 1027-1033.

Carniello MA, Silva RS, Cruz MB, Guarim GN. 2010. Quintais urbanos de Mirassol D’Oeste-MT, Brasil: uma abordagem etnobotânica. Acta Amazônica 40: 451-470.

Castellucci S, Lima IS, Nordi N, Marques JGW. 2000. Plantas medicinais relatadas pela comunidade residente na estação ecológica de Jataí, município de Luís Antônio/SP: uma abordagem Etnobotânica. Revista Brasileira de Plantas Medicinais, Botucatu 3: 51-60.

Castro AP, Fraxe TJP, Santiago JL, Matos RB, Pinto IC. 2009. Os sistemas agroflorestais como alternativa de sustentabilidade em ecossistemas de várzea no Amazonas. Acta Amazônica 39: 279-288.

Castro AP, Fraxe TJ, Pereira HS, Kinupp VF. 2012. Etnobotânica das variedades locais do cará (Dioscorea spp.) cultivados em comunidades no município de Caapiranga, estado do Amazonas. Acta Botanica Brasilica 26: 658-667.

Chaves EMF, Barros RFM. 2012. Diversidade e uso de recursos medicinais do carrasco na APA da Serra da Ibiapaba, Piauí, Nordeste do Brasil. Revista Brasileira de Plantas Medicinais, Botucatu 14: 476-486.

Christo AG, Bruni RRG, Kruel VSF. 2006. Uso de recursos vegetais em comunidades rurais limítrofes à reserva Biológica de Poço das Antas, Silva Jardim, Rio de Janeiro: estudo de caso na Gleba Aldeia Velha. Rodriguésia 57: 519-542. 
Christo AG, Bruni RRG, Silva AG. 2010. Local knowledge on medicinal plant gardens in a rural community near the Atlantic Rain Forest, southeastern Brazil. Revista Brasileira de Farmacognosia 20: 494-501.

Costa JR, Mitja D. 2010. Uso dos recursos vegetais por agricultores familiares de Manacapuru (AM). Acta Amazônica 40: 49-58.

Costa VP, Mayworm MAS. 2011. Plantas medicinais utilizadas pela comunidade do bairro dos Tenentes - município de Extrema, MG, Brasil. Revista Brasileira de Plantas Medicinais, Botucatu 13: 282-292.

Costa-Neto EM, Oliveira MVM. 2000. The use of the Medicinal plants in the country of Tanquinho, Estate of Bahia, Northeastern Brazil. Revista Brasileira de Plantas Medicinais, Botucatu 2: 1-8.

Cunha MC. 1999. Populações tradicionais e a Convenção da Diversidade Biológica. Estudos Avançados 13: 147-163.

Cunha AS, Bortolotto IM. 2011. Etnobotânica de Plantas Medicinais no Assentamento Monjolinho, município de Anastácio, Mato Grosso do Sul, Brasil. Acta Botanica Brasilica: 25: 685-698.

Cunha-Lima ST, Rodrigues ED, Melo T, et al. 2008. Levantamento da flora medicinal usada no tratamento de doenças metabólicas em Salvador, BA- Brasil. Revista Brasileira de Plantas Medicinais, Botucatu 10: 83-89.

Cunha-Lima ST, Rodrigues ED, Alves C, et al. 2012. The use of medicinal plants by an indigenous Pataxó community in NE Brazil. Revista Brasileira de Plantas Medicinais, Botucatu 14: 84-91.

Dorigoni PA, Ghedini PC, Fróes LF, et al. 2001. Levantamento de dados sobre plantas medicinais de uso popular no município de São João do Polêsine, RS - Relação entre enfermidades e espécies utilizadas. Revista Brasileira de Plantas Medicinais, Botucatu 4: 69-79.

Eichemberg MT, Amorozo MCM, Moura LC. 2009. Species composition and plant use in old urban homegardens in Rio Claro, Southeast of Brasil. Acta Botanica Brasilica 23: 1057-1057.

Espinosa MM, Bieski IGC, Martins DTO. 2012. Probability sampling design in ethnobotanical surveys of medicinal plants, Revista Brasileira de Farmacognosia 22: 1362-1367.

Falcão DQ, Costa ER, Menezes FS, Kuster RM. 2006. Ethnopharmacological study of plants used topically by the community of Macabú (RJ) and its essential oil chemistry evaluation. Revista Brasileira de Plantas Medicinais, Botucatu 8: 172-174.

Ferraz JSF, Albuquerque PA, Meunier IMJ. 2006. Valor de uso e estrutura da vegetação lenhosa às margens do riacho do Navio, Floresta, $\mathrm{PE}$, Brasil. Acta Botanica Brasilica 20: 125-134.

Ferreira SN, Sampaio MJAM. 2013. A Legislação de acesso e repartição de benefícios no Brasil. In: Ferreira SN, Sampaio MJAM. (eds.) Biodiversidade e conhecimentos tradicionais associados: Implementação da legislação de acesso e repartição de benefícios no Brasil. São Paulo, Sociedade Brasileira para o Progresso da Ciência. p. 147-152.

Florentino ATN, Araújo EL, Albuquerque UP. 2007. Contribuição de quintais agroflorestais na conservação de plantas da Caatinga, município de Caruaru, PE, Brasil. Acta Botanica Brasilica 21: 37-47.

Fonseca-Kruel VS, Araujo DSD, SÁ CFC, Peixoto AL. 2009. Quantitative ethnobotany of a restinga Forest fragment in Rio de Janeiro, Brazil. Rodriguésia 60: 187-202.

Fonseca-Kruel VS, Peixoto AL. 2004. Etnobotânica na Reserva Extrativista Marinha de Arraial do Cabo, RJ, Brasil. Acta Botanica Brasilica 18: 177-190.

Franco EAP, Barros RFM. 2006. Uso e diversidade de plantas medicinais medicinais no Quilombo Olho D’água dos Pires, Esperantina, Piauí. Revista Brasileira de Plantas Medicinais, Botucatu 8: 78-88.

Freitas AVL, Coelho MFB, Maia SSS, Azevedo RAB. 2012. Plantas medicinais: um estudo etnobotânico nos quintais do Sítio Cruz, São Miguel, Rio Grande do Norte, Brasil. Revista Brasileira de Biociências, Porto Alegre 10: 48-59.

Freitas JC, Fernandes MEB. 2006. Uso de plantas medicinais pela comunidade de Enfarrusca, Bragança, Pará. Boletim do Museu Paraense Emílio Goeldi, Ciências Naturais, Belém 1: 11-26.

Gandolfo EF, Hanazaki N. 2011. Etnobotânica e urbanização: conhecimento e utilização de plantas de restinga pela comunidade nativa do distrito do Campeche (Florianópolis, SC). Acta Botanica Brasilica 25: 168-177.
Garlet TMB, Irgang BE. 2001. Plantas medicinais utilizadas na medicina popular por mulheres trabalhadoras rurais de Cruz alta, Rio Grande do Sul, Brasil. 2001. Revista Brasileira de Plantas Medicinais, Botucatu 4: 9-18.

Ghedini PC, Dorigoni PA, Almeida CE, Ethur ABM, Lopes AMV, Záchia RA. 2002. Levantamento de dados sobre plantas medicinais de uso popular no município de São João do Polêsine, RS, II - Emprego de preparações caseiras de uso medicinal. Revista Brasileira de Plantas Medicinais, Botucatu 5: 46-55.

Giraldi M, Hanazaki N. 2010. Uso e conhecimento tradicional de plantas medicinais no Sertão do Ribeirão, Florianópolis, SC, Brasil. Acta Botanica Brasilica 24: 395-406.

Gomes TB, Bandeira FPSF. 2012. Uso e diversidade de plantas medicinais em uma comunidade quilombola no Raso da Catarina, Bahia. Acta Botanica Brasilica 26: 796-809.

Gonzales-Perez SE, Coelho-Fereira, Robert P, Garces CL. 2012. Conhecimento e usos do babaçu (Attalea speciosa Mart. E Attalea eichleri (Drude) A. J. Hend.) entre os Mebêngôkre-Kayapó da Terra Indígena Las Casas, estado do Pará, Brasil. Acta Botanica Brasilica 26: 295-308.

Grandi TSM, Trintade JA, Pinto MJF, Ferreira LL, Catella AC. 1989. Plantas medicinais de Minas Gerais, Brasil. Acta Botanica Brasilica 3: 185-224.

Hanazaki N, Souza VC, Rodrigues RR. 2006. Ethnobotany of rural people from the boundaries of Carlos Botelho State Park, São Paulo State, Brazil. Acta Botanica Brasilica 20: 899-909.

Hunn E. 2007. Ethnobiology in four phases. Journal of Ethnobiology 27: 1-10.

Jesus NZT, Lima JCS, Silva RM, Espinosa MM, Martins DTO. 2009. Levantamento etnobotânico de plantas popularmente utilizadas como antiúlceras e antiinflamatórias pela comunidade de Pirizal, Nossa Senhora do Livramento-MT, Brasil. Revista Brasileira de Farmacognosia 19: 130-139.

Lanini J, Duarte-Almeida JM, Nappo S, Carlini EA. 2009. "O que vêm da terra não faz mal" - relatos de problemas relacionados ao uso de plantas medicinais por raizeiros de Diadema/SP. Revista Brasileira de Farmacognosia 19: 121-129.

Leitão F, Kruel VSF, Silva IM, Reinert F. 2009. Urban ethnobotany in Petrópolis and Nova Friburgo (Rio de Janeiro, Brazil). Revista Brasileira de Farmacognosia 19: 333-342.

Lima ILPL, Scariot A, Medeiros AS, Sevilha AC. 2012. Diversidade e uso de plantas do Cerrado em comunidade de Geraizeiros no norte do estado de Minas Gerais, Brasil. Acta Botanica Brasilica, 26: 675-684.

Lima PGCL, Ferreira MC, Oliveira R. 2011. Plantas medicinais em feiras e mercados públicos do Distrito Florestal Sustentável da BR-163, estado do Pará, Brasil. Acta Botanica Brasilica 25: 422-434.

Liporacci HSN. 2014. Plantas Medicinais e Alimentícias na Mata Atlântica e Caatinga: Uma revisão bibliográfica de cunho etnobotânico. Msc Thesis, Universidade Federal de Santa Catarina, Brazil.

Lucena CM, Costa GM, Sousa RF, et al. 2012. Conhecimento local sobre cactáceas em comunidades rurais na mesorregião do sertão da Paraíba (Nordeste, Brasil). Biotemas 25: 281-291.

Macedo M, Ferreira AR. 2004. Plantas medicinais usadas para tratamentos dermatológicos, em comunidades da Bacia do Alto Paraguai, Mato Grosso. Revista Brasileira de Farmacognosia 14: 40-44.

Macedo M, Ferreira AR. 2005. Plantas hipoglicemiantes utilizadas por comunidades tradicionais na Bacia do Alto Paraguai e Vale do Guaporé, Mato Grosso-Brasil. Revista Brasileira de Farmacognosia 14: 45-47.

Maioli-Azevedo V, Fonseca-Kruel VS. 2007. Plantas medicinais e ritualísticas vendidas em feiras livres no Município do Rio de Janeiro, RJ, Brasil: estudo de caso nas zonas Norte e Sul. Acta Botanica Brasilica 21: $263-275$.

Marchese JA, Ming L, Franceschi L. et al. 2009. Medicinal plants used by "Passo da Ilha" rural community in the city of Pato Branco, southern Brazil. Anais da Academia Brasileira de Ciências 81: 691-700.

Marinho ML, Alves MS, Rodrigues MLC, et al. 2007. A utilização de plantas medicinais em medicina veterinária: um resgate do saber popular. Revista Brasileira de Plantas Medicinais, Botucatu 9: 64-69.

Marinho MGV, Silva CC, Andrade LHC. 2011. Levantamento etnobotânico de plantas medicinais em área de caatinga no município de São José de Espinharas, Paraíba, Brasil. Revista Brasileira de Plantas Medicinais, Botucatu 13: 170-182. 
Marodin SM, Baptista LRM. 2001. O uso de plantas com fins medicinais no município de Dom Pedro de Alcântara, Rio Grande do Sul, Brasil. Revista Brasileira de Plantas Medicinais, Botucatu 4: 57-68.

Marodin SM, Baptista LRM. 2002. Plantas medicinais do Município de Dom Pedro de Alcântra, Estado do Rio Grande do sul, Brasil: espécies, famílias e usos em três grupos da população humana. Revista Brasileira de Plantas Medicinais, Botucatu 5: 1-9.

Martins ER, Oliveira LO. 2005. Revista Brasileira de Plantas Medicinais, Botucatu 7: 6-10.

Martins LGS, Senna-Valle L, Pereira NA. 2005. Princípio ativos e atividades farmacológicas de 8 plantas popularmente conhecidas por nome de medicamentos comerciais. Revista Brasileira de Plantas Medicinais, Botucatu 7: 73-76.

Mattos PP, Konig A, Freire FAM, Aloufa MAI. 2012. Etnoconhecimento e percepção dos povos pesqueiros da Reserva Ponta do Tubarão acerca do ecossistema manguezal. Revista Brasileira de Biociências, Porto Alegre 10: 481-489.

McClatchey W. 2006. Improving quality of international ethnobotany research and publications. Ethnobotany Research \& Applications 4: 1-9.

Medeiros MFT, Fonseca VS, Andreata RHP. 2004a. Plantas medicinais e seus usos pelos sitiantes da Reserva Rio das Pedras, Mangaratiba, RJ, Brasil. Acta Botanica Brasilica 18: 391-399.

Medeiros MFT, Silva HP, Senna VL. 2004b. Estudo preliminar do uso de plantas medicinais por benzedores e outros informantes de Santa Tresa, Espírito Santo, Brasil. Revista Brasileira de Farmacognosia 14: 19-21.

Melo S, Lacerda VD, Hanazaki N. 2008. Espécies de Restinga conhecidas pela comunidade do Pântano do Sul, Florianópolis, Santa Catarina, Brasil. Rodriguésia 59: 799-812.

Merétika AHC, Peroni N, Hanazaki N. 2010. Local knowledge of medicinal plants in three artisanal fishing communities (Itapoá, Southern Brazil), according to gender, age, and urbanization. Acta Botanica Brasilica 24: 386-394.

Miller RP, Wandelli EV, Grenand P. 1989. Conhecimento e utilizaçâo da floresta pelos índios Aimiri-atroari do rio Camanau - Amazonas. Acta Botanica Brasilica 3: 47-56.

Miranda TM, Hanazaki N. 2008. Conhecimento e uso de recursos vegetais de restinga por comunidades das ilhas do Cardoso (SP) e de Santa Catarina (SC), Brasil. Acta Botanica Brasilica 22: 203-215.

Miranda TM, Hanazaki N, Govone JS, Alves DMM. 2011. Existe utilização efetiva dos recursos vegetais conhecidos em comunidades caiçaras da Ilha do Cardoso, estado de São Paulo, Brasil? Rodriguésia 62: 153-169.

MMA - Ministério do Meio Ambiente. 2000. Convenção sobre a diversidade Biológica. Série Biodiversidade, $\mathrm{n}^{\circ} 1$. Brasília - Brasil.

MMA - Ministério do Meio Ambiente. 2005. Regras para o Acesso Legal ao Patrimônio Genético e Conhecimento Tradicional Associado. Departamento do Patrimônio Genético. Brasília - Brasil.

MMA - Ministério do Meio Ambiente. Patrimônio genético: Conselho de Gestão do Patrimônio Genético. http://www.mma.gov.br/patrimonio-genetico/conselho-de-gestao-do-patrimonio-genetico. 25 Sep. 2013.

Moerman DE. 2005. An open letter to SEB members, and readers of Economic Botany, from the editor in chief. Economic Botany 59: 309-310.

Morais SM, Dantas JDP, Silva ARA, Magalhães EF. 2005. Plantas medicinais usadas pelos índios Tapebas do Ceará. Revista Brasileira de Farmacognosia 15: 169-177.

Negrelle RRB, Fornazzari KRC. 2007. Estudo etnobotânico em duas comunidades rurais (Limeira e Ribeirão Grande) de Guaratuba (Paraná, Brasil). Revista Brasileira de Plantas Medicinais Botucatu 9: 36-54.

Negrelle RRB, Tomazzoni MI, Ceccon MF, Valente TP. 2007. Estudo etnobotânico junto à Unidade Saúde da Família Nossa Senhora dos Navegantes: subsídios para o estabelecimento de programa de fitoterápicos na Rede Básica de Saúde do município de Cascavel (Paraná). Revista Brasileira de Plantas Medicinais, Botucatu 9: 6-22.

Nunes GP, Silva MF, Resende UM, Siqueira JM. 2003. Plantas Medicinais comercializadas por raizeiros no Centro de Campo Grande, Mato Grosso do sul. Revista Brasileira de Farmacognosia 13: 83-92.

Nunes JD, Nery PS, Figueiredo LS, Costa CA, Martins ER. 2012. O extrativismo da fava d'anta (Dimorphandra mollis Benth.) na região do Norte de Minas Gerais. Revista Brasileira de Plantas Medicinais, Botucatu 14: 370-375.
Oliveira DR, Costa ALM, Leitão GG, Castro NG, Santos JP, Leitão SG. 2011. Estudo etnofarmacognóstico da saracuramirá (Ampelozizyphus amazonicus Ducke), uma planta medicinal usada por comunidades quilombolas do Município de Oriximiná-PA, Brasil. Acta Amazônica 4: 383-392.

Oliveira ECS, Trovão DMBM. 2009. O uso de plantas em rituais de rezas e benzeduras: um olhar sobre esta prática no estado da Paraíba. Revista Brasileira de Biociências, Porto Alegre 7: 245-251.

Oliveira ER, Menini-Neto L. 2012. Levantamento etnobotânico de plantas medicinais utilizadas pelos moradores do povoado de Manejo, Lima Duarte-MG. Revista Brasileira de Plantas Medicinais, Botucatu 14:311-320.

Oliveira FC, Albuquerque UP, Fonseca-Kruel VS, Hanazaki N. 2009. Avanços nas pesquisas etnobotânicas no Brasil. Acta Botanica Brasilica 23: 590-605.

Oliveira FCS, Barros RFM, Moitaneto JM. 2010a. Plantas medicinais utilizadas em comunidades rurais de Oeiras, semiárido piauiense. Revista Brasileira de Plantas Medicinais, Botucatu 12: 282-301.

Oliveira GL, Oliveira AFM, Andrade LHC. 2010b. Plantas medicinais utilizadas na comunidade urbana de Muribeca, Nordeste do Brasil. Acta Botanica Brasilica 24: 571-577.

Oliveira HB, Kffuri CW, Casali VWD. 2010c. Ethnopharmacological study of medicinal plants used in Rosário da Limeira, Minas Gerais, Brazil. Revista Brasileira de Farmacognosia 20: 256-260.

Parente CET, Rosa MMT. 2001. Plantas comercializadas como medicinais no Município de Barra do Piraí, RJ. Rodriguésia 52: 47-59.

Pasa MC, Soares JJ, Neto GG. 2005. Estudo etnobotânico na comunidade de Conceição-Açu (alto da bacia do rio Aricá Açu, MT, Brasil). Acta Botanica Brasilica 19: 195-207.

Patzlaff RG, Peixoto AL. 2009. A pesquisa em etnobotânica e o retorno do conhecimento sistematizado à comunidade: um assunto complexo. História, Ciências, Saúde - Manguinhos, Rio de Janeiro 16: 237-246.

Paulino RC, Henrique GPSA, Moura NOS, Coelho MFB, Azevedo RAB. 2012. Medicinal plants at the Sítio do Gois, Apodi, Rio Grande do Norte State, Brazil. Revista Brasileira de Farmacognosia 22: 29-39.

Pereira CO, Lima EO, Oliveira RAG, et al. 2005b. Abordagem etnobotânica de plantas medicinais utilizadas em dermatologia na cidade de João Pessoa-Paraíba, Brasil. Revista Brasileira de Plantas Medicinais, Botucatu 7: 9-17.

Pereira RC, Oliveira MTR, Lemos GCS. 2005a. Plantas utilizadas como medicinais no município de Campos de Goytacazes-RJ. Revista Brasileira de Farmacognosia 14: 37-40.

Perez-Ojeda del Arco A, Perez-Ojeda del Arco M, Tapia-Cortese S, Blancas NI. 2011. What have we forgotten? Returning data from Ethnobiological research to local communities. Bioremedation, Biodiversity and Bioavailability 5: 22-27.

Peroni N, Miranda TM, Hanazaki N. 2007. Aspectos específicos do acesso ao patrimônio genético e do conhecimento tradicional associado à biodiversidade. In: Boef WS, Thijssen MH, Ogliari JB, Sthapit BR. (eds.) Biodiversidade e agricultores: fortalecendo o manejo comunitário. Porto Alegre, L\&PM. p. 187-193.

Pilla MAC, Amorozo MCM. 2009. O conhecimento sobre os recursos vegetais alimentares em bairros rurais no Vale do Paraíba, SP, Brasil. Acta Botanica Brasilica 23: 1190-1201.

Pilla MAC, Amorozo MCM, Furlan A. 2006. Obtenção e uso das plantas medicinais no distrito de Martim Francisco, Município de MogiMirim, SP, Brasil. Acta Botanica Brasilica 20: 789-802.

Pinheiro CUB. 2002. Extrativismo, cultivo e privatização do jaborandi (Pilocarpus microphyllus Stapf ex Holm.; Rutaceae) no Maranhão, Brasil. Acta Botanica Brasilica 16: 141-150.

Pinto EPP, Amorozo MCM, Furlan A. 2006. Conhecimento popular sobre plantas medicinais em comunidades rurais de mata atlântica - Itacaré, BA, Brasil. Acta Botanica Brasilica 20: 751-762.

Pires MV, Abreu PP, Soares CS, et al. 2009. Etnobotânica de terreiros de candomblé nos municípios de Ilhéus e Itabuna, Bahia, Brasil. Revista Brasileira de Biociências, Porto Alegre 7: 3-8.

Platiau AFB, Varella MD. Diversidade biológica e conhecimentos tradicionais. Coleção Direito Ambiental. Belo Horizonte, Del Rey. 2004.

Poderoso AR, Hanazaki N, Dunaiski AJ. 2012. How is local knowledge about plants distributed among residents near a protected area? Ethnobiology and Conservation 1: 1-8. 
Ribeiro ASS, Palha MDC, Tourinho MM, Whiteman CW, Silva ASL. 2007. Utilização dos recursos naturais por comunidades humanas do Parque Ecoturístico do Guamá, Belém, Pará. Acta Amazônica 37: 235-240.

Ritter MR, Sobierajski GR, Schenkel, EP, Mentz LA. 2002. Plantas usadas como medicinais no município de Ipê, RS, Brasil. Revista Brasileira de Plantas Medicinais 12: 51-62.

Rocha AES, Silva MFF. 2005. Aspectos fitossociológicos, florísticos e etnobotânicos das palmeiras (Arecaceae) de floresta secundária no município de Bragança, PA, Brasil. Acta Botanica Brasilica 19: 657-667.

Rocha SFR, Scarda FM, Souza NN, et al. 2004. Uso de informações populares no delineamento de estratégias de uso, conservação e coleta de germoplasma de espécies medicinais do gênero Uncaria (Rubiaceae) na Reserva de Desenvolvimento Sustentável Mamirauá (AM). Revista Brasileira de Plantas Medicinais 6: 28-35.

Rodrigues ACC, Guedes MLS. 2006. Utilização de plantas medicinais no Povoado Sapucaia, Cruz das Almas - Bahia. Revista Brasileira de Plantas Medicinais, Botucatu 8: 1-7.

Rodrigues E. Etnofarmacologia no Parque Nacional do Jaú, AM. 1998. Revista Brasileira de Plantas Medicinais 1: 1-14.

Rodrigues VEG, Carvalho DA. 2007. Levantamento etnobotânico de plantas medicinais no domínio dos cerrados na região do Alto Rio Grande - Minas Gerais. Revista Brasileira de Plantas Medicinais, Botucatu 9: 17-35.

Roman ALC, Santos JUM. 2006. A importância das plantas medicinais para a comunidade pesqueira de Algodoal. Boletim do Museu Paraense Emílio Goeldi. Ciências Naturais, Belém 1: 69-80.

Roque AA, Rocha RM, Loiola MIB. 2010. Uso e diversidade de plantas medicinais da Caatinga na comunidade rural de Laginhas, município de Caicó, Rio Grande do Norte (nordeste do Brasil). Revista Brasileira de Plantas Medicinais, Botucatu 12: 31-42.

Rosa RL, Barcelos ALV, Bampi G. 2012. Investigação do uso de plantas medicinais no tratamento de indivíduos com diabetes melito na cidade de Herval D' Oeste - SC. Revista Brasileira de Plantas Medicinais, Botucatu 14: 306-310.

Rufino MUL, Costa JTM, Silva VA, Andrade LHC. 2008. Conhecimento e uso do ouricuri (Syagrus coronata) e do babaçu (Orbignya phalerata) em Buíque, PE, Brasil. Acta Botanica Brasilica 22: 1141-1149.

Santilli J. 2009. Agrobiodiversidade e direito dos agricultores. São Paulo: Peirópolis.

Santilli J. 2013. Medida provisória n. 2.186-16, de 2001: algumas questões a serem revistas. In: Ferreira SN, Sampaio MJAM. (eds.) Biodiversidade e conhecimentos tradicionais associados: Implementação da legislação de acesso e repartição de benefícios no Brasil. São Paulo, Sociedade Brasileira para o Progresso da Ciência. p. 285-292.

Santos EB, Dantas GS, Santos HB, Diniz MFFM, Sampaio FC. 2009. Estudo etnobotânico de plantas para problemas bucais no município de João Pessoa, Brasil. Revista Brasileira de Farmacognosia 19: 321-324.

Santos JFL, Amorozo MCM, Ming LC. 2008. Uso Popular de plantas medicinais na comunidade rural da Vargem Grande, Município de Natividade da Serra, SP. Revista Brasileira de Plantas Medicinais, Botucatu 10: 67-81.

Santos RS, Coelho-Ferreira M. 2012. Estudo etnobotânico de Mauritia flexuosa L. f.(Arecaceae) em comunidades ribeirinhas do Município de Abaetetuba, Pará, Brasil. Acta Amazônica 42: 1-10.

Scoles R. 2009. El Quintal y Las Frutas: Recursos Económicos y Alimentares en la Comunidad Negra de Itacoã, Acará, Pará, Brasil. Acta Amazônica 39: 1-12.

Shanley P, Laird SA. 2002. "Devolvindo": hacienda que los resultados de la investigación Sean relevantes para los grupos locales y para la conservación. In: Laird SA. (ed.) Biodiversidad y conocimiento tradicional: participación equitativa em práctica. Montevideo, Editorial Nordan-Comunidad. p. 133-153.

Silva ACO, Albuquerque UP. 2005. Woody medicinal plants of the caatinga in the state of Pernambuco, (Northeast Brazil). Acta Botanica Brasilica 19: 17-26.

Silva AJR, Andrade LHC. 2005. Etnobotânica nordestina: estudo comparativo da relação entre comunidades e vegetação na Zona do Litoral - Mata do Estado de Pernambuco, Brasil. Acta Botanica Brasilica 19: 45-60.
Silva CSP, Proença CEB. 2008. Uso e disponibilidade de recursos medicinais no município de Ouro Verde de Goiás, GO, Brasil. Acta Botanica Brasilica 22: 481-492.

Silva FS, Ramos MA, Hanazaki N, Albuquerque UP. 2011. Dynamics of tradicional knowledge of medicinal plants in a rural community in the Brazilian semi-arid region. Revista Brasileira de Farmacognosia 21: 382-391.

Silva MAB, Melo LV, Ribeiro RV, et al. 2010. Levantamento etnobotânico de plantas utilizadas como anti-hiperlipidêmicas e anorexígenas pela população de Nova Xavantina-MT, Brasil, Revista Brasileira de Farmacognosia 20: 549-562.

Silva MIG, Gondim APS, Nunes IFS, Souza FCF. 2006b. Utilização de fitoterápiocs nas unidades de atenção a saúde da família no município de Maracanaú (CE). Revista Brasileira de Farmacognosia 16: 455-462.

Silva MS, Antoniolli AR, Batista JS, Mota CN. 2006a. Plantas medicinais usadas nos distúrbios do trato gastrointestinal no povoado Colônia Treze, Lagarto, SE, Brasil. Acta Botanica Brasilica 20: 815-829.

Silva TS, Freire EMX. 2010. Abordagem etnobotânica sobre plantas medicinais citadas por populações do entorno de uma unidade de conservação da caatinga do Rio Grande do Norte, Brasil. Revista Brasileira de Plantas Medicinais, Botucatu 12: 427-435.

Silva VA, Andrade LHC. 2002. Etnobotânica Xucuru: espécies místicas. Biotemas 15: 45-57.

Siviero A, Delunardo TA, Haverroth M, Oliveira LC, Mendonca AMS. 2011. Cultivo de Espécies Alimentares em Quintais Urbanos de Rio Branco, Acre, Brasil. Acta Botanica Brasilica 25: 549-556.

Siviero A, Delunardo TA, Haverroth M, Oliveira LC, Mendonça AMS. 2012. Plantas medicinais em quintais urbanos de Rio Branco, Acre. Revista Brasileira de Plantas Medicinais, Botucatu 14: 598-610.

Soares ELC, Vendruscolo GS, Eisinger SM, Záchia RA. 2004. Estudo Etnobotânico do uso dos recursos vegetais em São João do Polêsine, RS, Brasil, no período de outubro de 1999 a junho de 2001. Origem e fluxo do conhecimento. Revista Brasileira de Plantas Medicinais, Botucatu 6: 69-95.

Souza CD, Felfili JM. 2006. Uso de plantas medicinais na região de Alto Paraíso de Goiás, GO, Brasil. Acta Botanica Brasilica 20: 135-142.

Souza LF. 2007. Recursos vegetais usados na medicina tradicional do Cerrado (comunidade de Baús, Acorizal, MT, Brasil). Revista Brasileira de Plantas Medicinais, Botucatu 9: 44-54.

Ustulin M, Figueiredo BB, Tremea C, et al. 2009. Plantas Medicinais Comercializadas no Mercado Municipal de Campo Grande-MS. Revista Brasileira de Farmacognosia, 19: 805-813.

Vendruscolo GS, Mentz LA. 2006. Estudo da concordância das citações de uso e importância das espécies e famílias utilizadas como medicinais pela comunidade do bairro Ponta Grossa, Porto Alegre, RS, Brasil. Acta Botanica Brasilica 20: 367-382.

Verde VGM, Paula JR, Caneiro DM. 2003. Levantamento etnobotânico das plantas medicinais do cerrado utilizadas pela população de Mossâmedes (GO). Revista Brasileira de Farmacognosia 13: 64-66.

Verpoorte R, Houghton PJ, Heinrich M, et al. 2006. Editorial. Journal of Ethnopharmacology 103: 309-310.

Vieira TA, Rosa LS, Vasconcelos PCS, Santos MM, Modesto RS. 2007. Sistemas agroflorestais em áreas de agricultores familiares em Igarapé-Açu, Pará: caracterização florística, implantação e manejo. Acta Amazônica 37: 549-558.

Yuyama LKO, Aguiar JPL, Pantoja L, et al. 2007. Segurança/insegurança alimentar em famílias urbanas e rurais no estado do Amazonas: I. Validação de metodologia e de instrumento de coleta de informação. Acta Amazônica 37: 247-252.

Zeni ALB, Bósio F. 2006. Medicinal plants used in the Nova Russia, Brazilian Atlantic Rain Forest. Revista Brasileira de Plantas Medicinais, Botucatu 8: 167-171.

Zuchiwschi E, Fantini AC, Alves AC, Nivaldo P. 2010. Limitações ao uso de espécies florestais nativas pode contribuir com a erosão do conhecimento ecológico tradicional e local de agricultores familiares. Acta Botanica Brasilica 24: 270-282. 